\title{
The Church as Christ's broken body responding to the emerging global challenges in a divided world
}

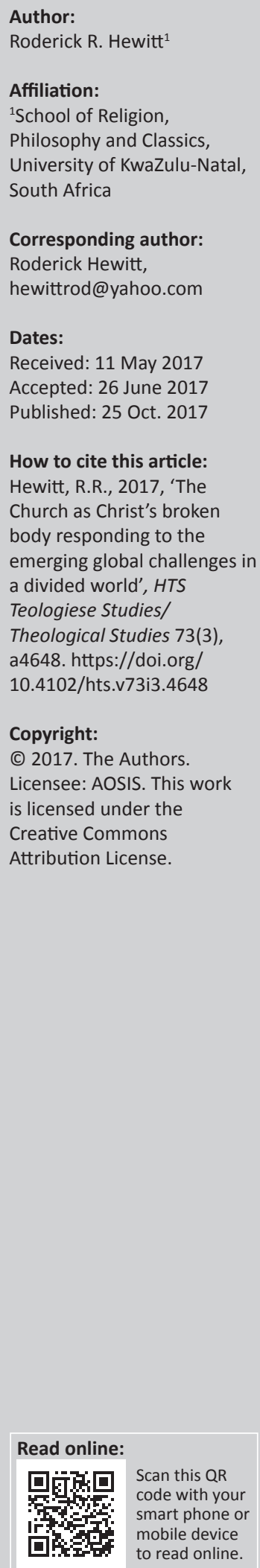

Public debate about the role of the church within society has gained momentum especially because the contemporary changing global political and economic landscape has resulted in deeply a divided world. People are asking questions about the missional identity and vocation of the church. If the church is the broken body of Christ in the world, what are the ways in which it is expressing that brokenness in practical ways? This vulnerable status necessitates modelling the politics of Jesus that risks putting up resistance against all threats that prevent people from experiencing fullness of life. The contemporary era of global governance is characterised by 'moral lowlifes' in political leadership that uses judicial and executive overreach to weaken democracy and empower the wealthy elites. Furthermore, the impact of technology and computation on shaping human relations has produced a consequential decline in human trust and relationships. Therefore, the missional agenda of the church as the broken body of Christ serving a divided world, calls for building life-affirming relationships that overcome dehumanising barriers.

\section{Introduction}

The thesis of this chapter argues that the Church's ecclesiological identity as the 'Body of Christ' as described by St. Paul (1 Cor 12:27; Rm 12:4-5) constitutes an important missional metaphor to interrogate its response to the emerging global challenges in a divided world. The church describes Christ as the Head of this body (Eph 5:23; Col 1:18) who sets the missional agenda for this 'gathered people' who are commissioned to serve the world in his name. The Christological significance of the church's identity as the body of Christ gives it both a human/empirical identity as a visible, concrete, gathered community of believers and a super-empirical reality that is not visible to the human eyes (Hegstad 2013). This body of Jesus is however a broken body that has experienced great pain, wounds and shame from human wrongdoing. The Church therefore is also a broken body and this brokenness is aptly described by what Henri Nouwen (1979) has coined as 'Wounded healers'. ${ }^{1}$ This state of brokenness seeks to serve others in a state of deep humility that recognises its own vulnerabilities.

The resurrected Jesus in his Emmaus accompaniment walk with his depressed and dejected followers who had witnessed his crucifixion and death at the hands of the political and religious authorities sought to explain the significance of his death that was not the end but only a precursor of something much more life transforming that God promised would happened (Lk 24:13-38). However, even though the resurrected Jesus was with them and taught them that the scriptures had promised about him, this knowledge did not on its own result in belief. Despite the 11-kilometer walk from Jerusalem to Emmaus that allowed sufficient time to know each other, the disciples still did not recognise the resurrected Christ as the same Jesus with whom they had journeyed with for about 3 years (24:16). It was only when they reached their destination at the house of Cleopas and they invited the stranger in to spend the night and share an evening meal that 'their closed eyes of faith' became opened and they recognised that it was Jesus who had accompanied them along the way. During the meal, they invited him to say the blessing for the meal and he took the bread, gave thanks, broke it and shared it with them. In doing so, they recalled their last Passover meal that they had with Jesus in which he also told them that it was a symbol of his broken body that was shared for the salvation of the world (24:31).

These disciples who became part of the early church interpreted their resurrection experience of seeing Jesus and the breaking of bread as a symbol of his broken body as an invitation to become witness of this life transforming power. They did not wait for the next day to share their experience but returned to Jerusalem soon after their meal to tell other disciples that they had seen the risen Jesus (24:31-34).

1.See also Joe Colletti perspectives on The Wounded Healer in Nouwen (1979). 
The Emmaus walk accompaniment experience serves as a signpost that the church in its visible and concrete expression must serve as a fellowship of people that belong, believe and become followers of Jesus and seek to bear witness to his salvific presence in the world. Therefore, this article will interrogate and identify the nature and quality of the church's missional response to the emerging challenges that confronts its ministry and mission in the contemporary divided world. The reflection uses a missio-political theological framework to engage and converse with the issues that are identified. This type of political theology is predicated on the need for church to embody sound theological and missional foundations in order to address the non-life giving public policies that work against the common good of the people and to present alternative policies that can replace those that are bequeathing death. Prof. Jan Rippentrop reflected on some reasons why she would refer to her theological identity as a political theologian. She offers the following five presumptive indicators as a framework using the phrase 'You might be a political theologian if ...':

1. You understand the Bible as inherently political.

2. You understand politics as more than partisan and governmental.

3. You believe God cares about the whole world - that is, about the polis.

4. You notice that theology affects whole systems (not just individuals).

5. You know that theology and faith produce action (not only thoughts) and belong in the world (as opposed to in 'ivory towers'). (Thomas 2017:1)

These five standards that are used by Rippentrop also embody the key theological indicators that embody the use of the concept 'missio-political' as the framework through which the church's response to the emerging global issues will be interrogated. The five indicators are also central to the missional identity of the church as the gathered people of God (ecclesia) who are called and sent by the Missio-Dei. This God of life embodies a triune-reciprocal relationship framework in which God the Creator is celebrated as a giver of life, Jesus as Saviour for the whole universe and the Holy Spirit as the divine sustainer who empowers life and renews the whole creation (Gn 2:7; Jn 3:8) (Keum 2012:1-5). The church as an ambassador of this Triune-God has no option but to be missional by giving radical transformative leadership to the issues that deny people life, especially those that live on the margins (2012:5-6). To live on the margins involves living in a permanent state of vulnerability because such persons are excluded from active participation in the political and economic decisions of their nations that shape their daily lives. Therefore, the missional witness of the Church must also be political in its public discourse because overcoming the threats to life necessitates that the church engage in transforming the power structures (2012:16).

\section{The changing global political landscape}

This section gives attention to identifying the factors that are shaping the global landscape and how they are redefining what it means to be human and the role of human relations in overcoming global challenges in a divided world. The fast-changing global landscape especially in the area of technological advancement is redefining what it means to be human and also greatly reducing trust in human relationship with one another and with the environment. The year 2016 was the year of a colossal political shift with the election of Donald Trump as President of the United States, being the most powerful military and economic nation in the world (Purdum 2016). His election and that of other developments such as the United Kingdom's referendum to leave the European Union (popularly termed as Brexit), Erdogan's victory in the Turkish referendum to become an executive President and Putin's push for Russia to become a global superpower have resulted in increased re-ascendency of extreme right-wing white supremacistinspired nationalism and many other -isms around the world. These leaders are part of a growing list of populist nationalist movements. In the South, the populist 'democratically elected' dictators of Africa stand out. This world order has normalised, legalised and legitimised leaders around the world to get away with gross human rights abuses. All these leaders are members of oligarchy and plutocracy wealthy - not grass-roots - but they use populism that they claim will empower the working classes. In reality, it became a global hoax, a deceptive instrument to further empower the wealthiest classes in society.

\section{Politics of judicial and executive overreach}

The contemporary era of political leadership in many influential nations can best be described as the 'ascendancy of moral lowlifes' (Hewitt 2010). According to Kenneth Roth of Foreign Policy journal, this age is on the verge of darkness because populism is challenging acceptable standards of tolerance, political centrism, diversity and pluralism (Roth 2017). A coalescing of all global ideological forces of hatred, sexism, xenophobia, indecency and anti-democratic populist movements are throwing overboard political correctness, values of decency, tolerance, truth-telling, compassion and simple common sense to create a toxic brew of global instability. Extremism is displacing the voices of reason and common sense as they take over some mainstream media, the social media and other forms of mass communication to transform the political and economic environment of many nations. In this age of global distrust in political systems of governance that specialise in deceiving the people, the role of cartoonists, comedians, artisans and truth-telling preachers in communicating resistance against Babylonian powers of empire (see Murrell 1998; Oliver 2003)² through hidden texts, subliminal sounds and pictures that can destabilise the status quo and contribute to its downfall. A new movie that was

2.Babylonian powers symbolise the world political, economic and religious forces and systems of inequality and injustice and constitute a destructive way of life for the systems of inequality and injustice and constitute a destructive way of life for the common people and creation. This term is used by Rastafari to denote systematic oppression perpetrated by evil powers of governance that are against their interest. The army and police are used by the State as their representatives to uphold unjus laws with their violence and corrupt behaviour. The concept of Babylon is borrowed from the Biblical symbol utilised in Revelation19-21 and Psalm 137, and is interpreted as an evil spiritual force that mitigates against 'upliftment' of the human spirit. 
released December 10, 2016 was poignantly named: The Rouge One! It explored a world overwhelmed by imperial and systemic evil (Kermode 2016). This Star Wars spin-off story is critiqued by Mark Kermode (2016) as offering a message that 'Rebellions are built on hope'. The resistance movement needed the coming together of a network of diverse persons to work together for the common good.

\section{The decline of democratic forms of governance}

Many nations have embraced a 'western-style' democratic model of governance with promises that the system is better able to deliver better services to meet the needs of the people (Hewitt 2014). However, poor leadership provided by competing political parties addicted to their own narrow selfinterest have to a great extent failed to provide good quality of governance. They usually achieved electoral victory but fail to provide sufficient economic gains that address progressive poverty, high inequalities and exclusion for the common people from the economic gains (Ross et al. 2016:474-477). The global strategy to undermine democracy seems to:

- undermine the judiciary and rule of law

- consistently lie without shame and never apologise, if caught red-handed and lie again

- unaccountability of the leader who is amoral

- appoint loyalists who never question their leader

- deceive the people to vote for an impotent and corrupt political party that sends people to the parliament to pass laws to benefit the economic and political elites

- buy out sections of the religious establishment whose leaders are lovers of money and power and can be easily corrupted to mis-educate their faith community into political acceptance and support of evil.

Francis Schaeffer classified this era as the Trumpocalypse (Schaefer 2017). The election of Trump as President of the United States of America has in part contributed to the reascendency of white supremacy ideology with its extreme nationalistic political and economic agenda that is supported by conservative evangelical Christianity. The main thrust of this agenda prioritises 'profits and power' and 'systematically' destroys governmental institutions (Chomsky 2017). The reascendency entry of the Alt-right ${ }^{3}$ white supremacy and nationalism officially entered the Western World standard model of governance and public discourse. Already it has emboldened forces of hate around the world and is forming new alliances. The consequence will be far-reaching for the ministry and mission of the church globally.

\section{Failed neoliberal policies have contributed to emergence of backlash from the right}

When those who once advocated, celebrated and respected fundamental rights and values of being human allow by

3.Alt-right is defined as: An ideological grouping associated with extreme conservative or reactionary viewpoints, characterised by a rejection of mainstream politics and
by the use of online media to disseminate deliberately controversial content. See by the use of online media to disseminate deliberately controver
http://www.bbc.com/news/uk-37995600 (viewed April 26, 2017). design or default a leader to devalue or destroy those moral and legal standards, they become difficult to be restored and their nations increasingly become inhumane, fearful, unstable and insecure, giving rise to internal and external conflicts. A dark epiphany in diminished democratic governance is enveloping the world.

In context where government policies destroy the environment for the sake of unjust profit for the wealthy minority, the gospel imperative invites the followers of Jesus to resist. Citizens must therefore be extremely careful not to elect or select leaders of their country who are known to suffer from deep inferiority complex, relational inadequacy that cannot emphasise with the weak, possess a character trait that is amoral and demonstrate incompetence in educational standards, which is required for nation building. Such leaders, if allowed by the people because of their voting apathy, will compensate their inadequacies by replacing democratic systems and institutions of governance that hold them accountable with dictatorship rule. The consequences for such nations and the wider world will be incalculable.

Ralph Keys in his text on The Post-Truth Era: Dishonesty and Deception in Contemporary Life, states that: 'In the post-truth era, borders blur between truth and lies, honesty and dishonesty, fiction and nonfiction. Deceiving others becomes a challenge, a game, and ultimately a habit' (Keyes 2004). If the goal of the leader is to gain the public allegiance for a controversial political agenda, then any means must be used to tell the people what they find that emotionally connects with their identity. Therefore, a nationalist brand of identity politics has now gained strong global traction. Facts and reasoning no longer matter. Self-willed fanatics no longer see the need to become educated because delusion offers greater security. Lies that are repeated many times through social media become true! What counts is what emotionally connects with the people. Such persons embrace cultic leaders, charlatan messiahs and sociopath demagogues that promote paranoid xenophobes.

\section{The descent into liberal authoritarianism and the delusion of democracy}

Cultural theorist, Stuart Hall, calls the emerging new forces of fear, hate, envy and resentment that are setting the political agenda as authoritarian populism (Mbembe 2016) in which growing and uncontrollable inequality triggers new forms of class struggles and social conflicts. This new world order has normalised, legalised and legitimised authoritarian leaders around the world to get away with gross human rights abuses. These manipulate distrust of institutions that give stability to society. All of these new deceptive political saviours are members of oligarchy and plutocracy wealthy not the grass-roots left behind ones but they use populism that they claim will empower the poor and working classes. In reality, it became a global hoax, a deceptive instrument to further empower the wealthiest classes in society. Nations are 
tricked by their election system that is bought by those with lots of money to voting for strong populist supreme leader who is uncritically followed, obeyed and defended no matter how wrong his policies are for the long-term well-being of the nation. There is a global uncontrollable anger against institutional power systems that fail to deliver their promises. In many societies, especially among alienated young people who live on the margins, they are extremely angry about what's going on in a nation that does not give a damn about their future. Many have lost trust in the country and its leaders who are considered to be a grossly out-of-touch with no appetite for flexibility and fundamental change.

Leaders who are pathologically mendacious cannot exercise moral authority over others and hold them accountable for lying. Lying has been legitimised by rogue leaders and their supporting governments as a better alternative to truth because it achieves result. Chomsky argues in 'Manufacturing Consent' -in his 1988 critique of 'the political economy of the mass media' with Edward S. Herman - that the mass media sells us the idea that we have political agency. Their 'primary function ... in the United States is to mobilise support for the special interests that dominate the government and the private sector' (Jones 2017).

\section{Failure of liberal theology and politics of the left}

An important controversial issue that calls for serious debate is the need to interrogate the role that Liberal Theology and Politics of the Left have played in contributing to the rise and ascendency of the Religious right, Christian fundamentalism and the prosperity Gospel culture in centres of political and economic power that influence the populist governments of the Right and their extreme nationalist priority political and economic agenda. The US political blogger, Sam Harris (2017) argues on 'Why Trump won?' and identified that to a great extent the dis-connecting politics of the left helped to shape the environment that paved the way for the rise of the extreme Right. Voters voted out of fear and distrust of liberals and their soft, weak and unconvincing response to people's security fears linked to religious extremism, Islamic terrorism and immigration. The political left were dismissed as irrelevant to the postmodern era with no sustainable solutions to the contemporary challenges. Instead of taking responsibility for their incompetence and failure in policy framing and implementation, the political left has resorted to simply blaming capitalism and big business for everything, failing to speak honestly on issues that affect the fundamental security of the state, blaming everything on the oppression of the political right and accusing them of racism and bigotry. The years of social democracy that embraced openness and tolerance had resulted in many citizens being disenchanted with the political project and ceasing to vote in national and local elections. Their disengagement created a broad space for the rise of identity populist politics that majored in being anti-establishment, isolationist, repudiation of the left and abandonment of political correctness. The disappointment with Western liberal democracy and its failure to deliver the dreams and hopes of a large number of citizens has resulted in psychotic disenchantment with the political status quo. This led many to vote out of exasperation, rejecting social justice and political correctness and instead opted by default to vote for deeply, morally and ethically flawed characters with a track record of conning the public. However, people viewed them as a better alternative to those pedalling an agenda of maintaining the status quo of the establishment.

\section{Is the age of humanism ending?}

Another important challenge facing the missional response of the church is to be found in the threats posed to being human in wholesome relationships with one another and the environment. These life-denying forces are greatly contributing to the decline and ridicule of virtues that build genuine human relationships such as love, care, compassion and kindness, especially for the weak and powerless. Achille Mbembe from the Wits Institute for Social and Economic Research argues that the best way to understand what is happening around us is to comprehend that the Age of Humanism is ending (Mbembe 2017). This era that began with enlightenment that caused the triumph of rationalisticand enlightenment-shaped mind that fashioned us as rational being is now found wanting and unable to deliver. Humanity's common future looks to be in jeopardy. New ways are therefore needed of knowing and processing the explosion of uncontrolled technocratic forces. The rational centre is no longer holding. Political, economic and religious certainties are no longer trusted. This is the age of political irrationalism in partnership with religious irrationalism.

\section{The emerging new humanity of 2017 and beyond}

The notion of humanity capacity has journeyed through all kinds of ideologies to pursue human happiness since the enlightenment into the modern, postmodern and now technocratic age in which we are experiencing the resurrection of mechanistic and materialist way of conceiving human actions. Technology-driven, intelligent chat boxes are providing information for consumers. Artificial intelligence will be taking over a number of human jobs and people will need to be retooled for new jobs. It is no longer about who is talking but what is talking to you?

Unadulterated, naked self-interest constitutes the motivation of being human. What's important constitutes whether the person has the power and influence to purchase something that is valuable. Persons are classified and recognised that they are fully human only if they possess enough money that can buy influence. Humans are increasingly being valued and treated as important as long as they have something to sell that people with purchasing power need. Therefore, those people without those monetary resources to purchase will therefore be deemed powerless. The consequences are far-reaching for social cohesion insofar that their marginalisation may lead to the development of a deep resentment and anger for those who possess and control political and economic power. 


\section{Rise in digital technologies and computational age and the consequential decline in human trust and relationships}

Another important challenge for the missional response of the church is the contemporary era of digital and computational impact of technologies on human development. The new humanity is being born fully wired from birth. The emergence of digital technologies and computational media has unleashed advancement in communication technologies that make life in the contemporary era so different from that of a few decades ago. Through the use smart phones and computers, mega data are gathered and analysed on people's movement and use of the Internet and the relevant information is sent to marketer of different institutions that wish to sell us something. Through algorithmic computer programming method, big data are gathered about all human beings that participate in the global market place. Technology seems to be the supreme controller of human life. ${ }^{4}$

This technocratic godlike reality that controls and influences political, economic, security and even religious landscape is increasingly eroding and weakening trust in the traditional modes and/or space of participation in the different institutions of society. New forms of networking have evolved that challenge traditional forms of governance in party politics and church. Institutions that are deemed not to be relevant to people's needs will lose the public's trust, support and participation. People no longer cling to loyalty that does not deliver relevant service. As people seek to cope during this age of automation, intentional effort must be given to life-long learning in order for them not to become commoditised and enslaved. The addictive allegiance to the invincibility of technology over human lives therefore offers grace risk that may seriously undermine and weaken the capacity of human beings to trust each other and to value each other based upon the quality of the their relationships.

\section{The church as a missional broken body}

In what ways can the church as 'the broken body of Christ' sent to serve the world offer an authentic missional response to the challenges that have been identified? Can the church 'Become the Gospel' (Gorman 2015) ${ }^{5}$ that results in the transformation of lives and the social environment in which the church bears witness? When the church 'Become the Gospel', it leads to transformation of lives and the social environment in which it serves. Theosis is a transformative process in which the believer's goal is to seek to become like Jesus (2 Pt 1:4). The focus is on becoming like and imitating Jesus, the teacher who sets the standard for our lifestyle. It involves transformative actions of participation in the life

4.Shoqiran, F. (2017), is a Saudi writer and researcher who also founded the Riyadh philosophers group.

5.Theologically this kind of lifestyle can be described as embracing a spirituality of Theosis. In Eastern Orthodoxy tradition, theosis is a transformative process in which the believer's goal is to seek to become like Jesus (2 Pt 1:4). and character of the God of life as reflected in the Jesus ministry and mission (Carey 2016). Similar to the dysfunctional non-life-affirming political leadership that is corrupting the world order so too is the quality of some clergy leaders that are serving the church. In order to respond to the global challenges, church leaders must be able to embrace and practice the politics of Jesus that sought 'fullness of life' for all (Jn 10:10). When this is translated into the contemporary context, it necessitates the church to take side and opt for the radical discontinuity with the global dehumanising forces that are bequeathing death and destruction to human communities and the rest of creation. The links between global wealth, poverty and ecology affect the well-being of a community. This task constitutes one of the most urgent life-threatening challenges in the missional formation of church leaders to choose between serving God or the power of mammon (reference). A radical reappropriation of the God of life is needed in the contemporary era where expressions of faith has become commodified and packaged to be sold to the global market place like new drugs. According to Walter Wink (2014), we are Homo sapiens but only God is fully human:

God is HUMAN ... It is the great error of humanity to believe that it is human. We are only fragmentarily human, fleetingly human, brokenly human. We see glimpses of our humanness, we can only dream of what a more human existence and political order would be like, but we have not yet arrived at true humanness. Only God is human, and we are made in God's image and likeness - which is to say, we are capable of becoming human. (p. 102)

If according to Walter Wink, human beings are fragmentarily, fleetingly and brokenly human because only God is fully human, then this broken state when applied to followers necessitates repentance of living a life built on deception of being what they are not. Jesus declared that his body was broken for the world. Therefore, the church as the community that follows Jesus must themselves become broken in order to serve the world. For this to happen, radical acts of repentance must be experienced in order for the world to validate the authenticity of the church's ministry and mission.

\section{A ministry corrupted by love of money}

One area that is in urgent need of serious repentance is the perception that Church leaders and their faith community exist as money-making, profit-sharing businesses for private vested interests rather than being non-profit institutions committed to altruistic service of the people. There are stories of ministers, pastors, preachers, apostles, Prophets and Bishops preying on the vulnerable and fleecing them of the little that they have as the price for a miracle (Poobal 2013). This is one area of life that impacts heavily on the poor where there is very little protection against financial and sexual exploitation. Persons can become pastors with no system of accreditation except their claim to be sent by God in an age where there are many false gods. This area of the church's witness within the public arena constitutes a serious health 
and safety risk that must be addressed. Maybe churches and/or denomination should publish once every 2 years in high-circulation, national newspapers a list of their accredited clergy and the accredited institutions in which they were trained to help people to make the right choice about who they should trust.

This virus of greed that has affected some populist charismatic clergy is legitimised by an accompanying theology of prosperity that is effectively marketed by selectively using sections of the Bible that are taken out of their context and then fused with modern marketing techniques, linked with use of the mass media to convince many gullible believers that their faith when exercised in the way that is prescribed can be rewarded with health and wealth. The guaranteed result in the end is that the pastor is the one who gets enriched at the expense of the people. In this 'anything goes' religious landscape of self-made unaccountable pastors, prophets, evangelists, apostles and Bishops, the identity of church has been captured into becoming a corrupt business enterprise. The new Man of God and his wife (the First Lady) are principal owners of the business that market promises of healing and prosperity. This chapter therefore argues that communication of the Christian faith by sections of the clergy leadership has resulted in a devaluation of human being that is commoditised and measured by money to determine its functional value. People are easily fleeced by religious magicians and entertainers carrying out healing tricks that are done in the name of Jesus. In this deceptive landscape, reality is shaped less by the rules of reason and more by passions and emotions that can make people feel good.

\section{Focus on building authentic human relationships}

In this contemporary landscape, the God-like status of the market and the power of money are what validate truth. Harvey Cox states in his text 'The Market as God' (Cox 1999) that the market operates like a religious institution which has its own theology, doctrine and liturgy. Every working day the bell rings for trade to begin. It has its own saints, prophets, priests, elders and followers who believe it is the only way to bring salvation on earth. The market can therefore be described as a corrupt system designed to make the poor poorer. According to Daley and Cobbs (1989), there is a 'misplaced concreteness of the market because it falsely claims that:

Its strengths are to be found in its capacity to use independent, decentralised decisions to give rise not to chaos ... Individual consumers know their preferences better than anyone else and act directly to satisfy them in the marketplace. Individual producers know their own capacities and options better than anyone else and they too act on this information in the market. (pp. 44-45)

The deceptive appeal of the market as an economic engine that empowers the people for nation building belies the awesome forces of violence, injustice and de-humanising power at work that are designed to enrich the wealthy class at the expense of denying fullness of life, especially to those who live on the margins of society.

The struggle of this era is therefore all about what it means to be human. The real threat to the church's ministry and mission is whether it will be co-opted as a partner in the dehumanising agenda of the global economic forces of empire and facilitate the flow of wealth and power from vulnerable persons, communities, and countries to the more powerful (The ACCRA Confession 2007:6). ${ }^{6}$ These forces are at work with their mechanistic dehumanisation project that is classifying the human being as a commodity to be used for profit. Therefore, the most urgent missional agenda for the church in the world is to ensure that its identity, vocation and witness are consistently given to teaching, preaching and mission action that builds authentic human relationships modelled on the praxis of Jesus.

\section{Needed: New moral imagination to overcome violence and building wholesome relationships}

Neoliberal capitalism has commodified people and mortgaged their future to a continuous exposure to violence and threats to life (Mishra 2017). The missional response of the church in a context of violence that seems to be unstoppable in many nations, which are structured on economic and political inequality, calls for a missional engagement that works for economic justice. Governments demonstrate that they are out of touch with knowing and responding to the real needs of the people when they use piecemeal approaches to stamp out the problem of violence. It could be argued that their inability to overcome the violence has resulted in a deadly impact on the poor and suggested that the ruling elites see the death of the poor as a form of population control because their economic worth is minimal and their lives are not worth saving.

The poor and those who live on the margins of their nations, experience hypocrisy and commodification of justice in which the priorities of the security and judiciary of the state are designed to protect interest of the politically and economically powerful, rather than the serving the needs of the vulnerable. The poor knows and sees many of the powerful who have engaged in serious crimes dress up in suites and attend parliament, national prayer breakfast and using powerful lawyers to protect them from accountability. Until the powerful within the different nations are seen to be held accountable by the judiciary for their acts of injustice and if found guilty be sent to prison in the same way that that the poor are easily locked away for minimal offences, then crime and violence will continue to envelop many nations. Unless their human dignity and worth is restored and respected through equal rights and justice, violence will continue to weaken the very core of the nation.

The systematic violence that has enveloped the DNA of many nations constitutes a mutation of imperial forces of violence 6.http://presbyterian.typepad.com/files/accra-confession.pdf (accessed March 30, 2017). 
that crucified Jesus whose body was broken for the salvation of the world. Therefore, the church as the broken body of Jesus in the world must also confront the contemporary imperial violence that denies life with a new moral and ethical compass of resistance against the evil powers. At the core of violence in many local communities and nations is the absence of wholesome, life-affirming relationships. To overcome and move beyond the enslavement of violence, new moral imagination is required that can risk building relationships that embrace the others, even those considered to be enemies of the community and church. This new era of violence cannot be overcome by returning to what was considered normal. One must move on to a more vulnerable state of embracing the unknown and more risky environment of peace building.

\section{Conclusion}

This paper sought to interrogate the nature and quality of the church's missional response to the emerging challenges that confronts its ministry and mission in the contemporary divided world. Using the motif of the church's missional identity as the broken body of Christ in the world, the paper argues for a radical re-appropriation of the broken body of Christ as the God of life that is at work transforming lives. A broken body missional model of being church in the world necessitates re-reading the Bible and re-appropriating the 'apocalypse hermeneutics' to interrogate the challenges being unleashed by systemic evil of the imperial Babylon system. Burchell Taylor has argued that resistance and overcoming the politics of the Antichrist, demonic powers and principalities necessitates that the church advocates and practices the politics of God's sovereignty over all creation (Taylor 2006). This resistance by the church offers no guarantee for success but its allegiance to Christ, whose body was broken for the life of the world, necessitates risking failure rather than settling for non-involvement and unwilling to surrender even when weakened and close to death. This act of radical obedience cannot be postponed or delayed. It calls for an urgency of the now!

If the missional agenda of the church is to embrace the politics of Jesus, then it must be vigilant in maintaining critical distance to prevent being co-opted by (1) State theology, in which the church and succumbs to being captured by the state to serve its political agenda. (2) Settling for a comfortable conservative church theology that majors in maintenance and clergycentred mission and fails to equip the people of God for lifegiving ministry and mission beyond the walls of the church. The integrity, legitimacy, credibility and authenticity of Christian leaders will be determined not only by their educational achievement and competence but also by practical expressions of being the gospel that results in lifetransforming relationships.

Finally, everything that I've reflected upon can be summed up in a brief phrase: The ministry and mission of the church must therefore be 'Become the Gospel' that focuses on building life-giving relationships that overcome the de-humanising spirit of our age. The missional priority of the church is to authenticate the broken body of Christ through the church to incarnate relationships that become the living experience of the gospel. The Church must leave the safe haven of ministering behind 'closed doors' of the local church because of fear to become a church 'without walls' and to 'sit where the people sit' in order to listen and respond to their cries. Only then will the nation and people experience the transformative power of the gospel (Delbecq 2000).

\section{Acknowledgements Competing interests}

The author declares that he has no financial or personal relationships which may have inappropriately influenced him in writing this article.

\section{References}

Carey, G., 2016, Every theosis, viewed 04 April 2016, from http://www.christiancentury. org/reviews/22016-03/evertday-theosis

Chomsky, N., 2017, Republican party is the most dangerous organization in human history, viewed 26 April 2017, from http://www.independent.co.uk/news/world/ americas/noam-chomsky-republican-party-most-dangerous-organisation-humanhistory-us-politics-mit-linguist-a7706026.html

Cox, H., 1999, The market as God living in the new dispensation, viewed 30 February 2017, from https://www.theatlantic.com/magazine/archive/1999/03/the-marketas-god/306397/

Daley, H.E. \& Cobbs, J.B., Jr., 1989, For the common good (re directing the economy towards community, the environment, and a sustainable future), Beacon Press, Boston, MA.

Delbecq, L.A., 2000, Spirituality for business leadership, Santa Clara University, p. 2, viewed 03 April 2016, from http://web.lemoyne.edu/ oconnor/page2/assets/ jmi\%20delbecq.pdf

Gorman, J.M., 2015, Become the Gospel Paul, participation and mission, Eerdmans, Grand Rapids, MI.

Harris, S., 2017, Why trump won?, viewed 15 March 2017, from https://www.youtube. com/watch?v=jA_AxTzBBvl

Hegstad, H., 2013, The real church an ecclesiology of the visible, Pickwick Publications, Eugene, OR.

Hewitt, R.R., 2010, The Moral lowlife in political culture, viewed 04 April 2017, from http://jamaica-gleaner.com/gleaner/20100903/cleisure/cleisure2.html

Hewitt, R.R., 2014, 'Spirituality for democracy: Spiritual resources for democratic participation in the 21st century', Verbum et Ecclesia, AOSIS Publishing Services, Cape Town, viewed 30 April 2017, from http://verbumetecclesia.org.za/index. php/VE/article/view/1345/2247

Jones J., 2017, An animated introduction to Noam Chomsky's manufacturing consent and how the media creates the illusion of democracy, Open Culture, viewed n.d., from http://www.openculture.com/2017/03/an-animated-introduction-to-noamchomskys-manufacturing-consent.html

Kermode, M., 2016, viewed 30 April 2017, from https://www.theguardian.com/ film/2016/dec/18/rogue-one-star-wars-story-review

Keum, J., 2012, Together towards life: Mission and evangelism in changing landscapes, New WCC Affirmation on Mission and Evangelism, WCC-Commission on World Mission and Evangelism (CWME), Geneva, Switzerland.

Keyes, R., 2004, The post-truth era: Dishonesty and deception in contemporary life, viewed 26 April 2017, from http://www.ralphkeyes.com/the-post-truth-era/

Mbembe, A., 2016, 'The age of humanism is ending', Mail and Guardian, viewed n.d., from http://mg.co.za/article/2016-12-22-00-the-age-of-humanism-is-ending

Mbembe, A., 2017, 'Difference and self-determination', E-Flux, Journal \#80, viewed 29 April 2017, from http://www.e-flux.com/journal/80/101116/difference-and-selfdetermination/

Mishra, P., 2017, The age of Anger, viewed 02 March 2017, from https://www.theguardian. com/politics/2016/dec/08/welcome-age-anger-brexit-trump?CMP=share_btn_fb

Murrell, N.S., 1998, Chanting down Babylon: The Rastafari reader, Temple University Press.

Nouwen, J.M.H., 1979, The Wounded Healer, Image Book, New York, See also Joe Colletti perspectives on The Wounded Healer, viewed 30 April 2017, from http://www.urban-monk.org/images/PDFS/spiritual/The Wounded_Healer Draft_II.pdf

Oliver, S., 2003, Encyclopedia of Jamaican heritage, Twin Guinep Publishers, St Andrew, p. 35

Poobal, B.V., 2013, When pastors prey overcoming clergy sexual abuse of women, WCC Publications, Geneva. 
Purdum, 2016, 'The 2016 race isn't about issues. It's about character', Politico Magazine, viewed 29 April 2017, from http://www.politico.com/magazine/ story/2016/08/does-anyone-care-about-issues-anymore-or-only-whether-trumpis-crazy-214150\#ixzz4Gq5fyYct

Ross, R.K., Keum, J., Avtzi, K. \& Hewitt, R.R., 2016, Ecumenical missiology changing landscapes and new conceptions of missions, Regnum Books, Oxford Mission, UK.

Roth, K., 2017, We are on the Verge of Darkness, Foreign Policy, viewed 13 January 2017, from http://foreignpolicy.com/2017/01/12/we-are-on-the-verge-of-darknesspopulism-human-rightsdemocracy/?utm_source=Sailthru\&utm_medium=email\& utm_campaign=New\%20Campaign\&utm_term=Flashpoints

Schaefer, F., 2017, How to survive Trumpocalypse, 2017, viewed 26 January 2017, from http://www.patheos.com/blogs/frankschaeffer/2017/01/survive-trumpocalypsebuild-better-america-2017-new-years-resolution-actually-make-america-better/
Shoqiran, F., 2017, Robots have brought Anthropocentrism closer to its demise, viewed 30 April 2017, from http://english.alarabiya.net/en/views/news/middleeast/2017/03/18/Robots-have-brought-anthropocentrism-closer-to-its-demise. html

Taylor, B., 2006, Saying no to Babylon, a reading of the book of Daniel, Kingston, BKT, Jamaica.

The ACCRA Confession, 2007, The North American Covenanting for Justice Working Group, Reformed Church in America, Communication and Production Services, Grand Rapids, MI.

Thomas, E.L., 2017, You might be a political theologian if... Professor Jan Rippentrop Word Press, viewed 20 March 2017, from https://wetalkwelisten.wordpress. com/2017/03/20/you-might-be-a-political-theologian-if-prof-jan-rippentrop/

Wink, W. \& Berry, S., 2014, Just Jesus, my struggle to become Human, Crown Publishing, New York. 